\title{
Allocation of Labor Time on Pig Farming in Tenga District South Minahasa Regency
}

\author{
Nansi Margret Santa, Merry Adelien Veibe Manese, \\ Poulla Oliva Viviaan Waleleng Waleleng, Sutria Gabrilla Kaloh
}

Faculty of Animal Husbandry, University of Sam Ratulangi, Indonesia

Corresponding Author: Nansi Margret Santa

DOI: https://doi.org/10.52403/ijrr.20220150

\begin{abstract}
Pig farming in Tenga District, South Minahasa Regency were farming business that is carried out in rural areas, as a side business besides working on corn, rice and coconut farming. The amount of working time allocated by farmers to these businesses varies. This study aims to determine the factors that affect the allocation of labor time in pig farming. The sample location was determined using a purposive sampling method with the consideration that these villages had a large population of pigs, so that Tenga Village, Pakuure Village, and Pakuweru Village were selected in Tenga District, South Minahasa Regency. The sample was determined using the total quota sampling method so that there were 37 farmers. The model used to analyze the factors that influence the allocation of labor time in pig farming is multiple linear regression. The results showed that the allocation of labor time in pig farming was jointly influenced by the allocation of labor time in farming, wages for working in pig farming, the number of livestock ownership and the number of family members. Factors that greatly influence the allocation of labor time in pig farming are the allocation of labor time on farming and wages on pig farming.
\end{abstract}

Keywords: Pig farming, labor time, allocation

\section{INTRODUCTION}

Community welfare was achieved if they have a certain amount of money to pay for their daily needs. Livestock farming is one of the businesses in the agricultural sector that was able to provide a certain amount of money to farm households. Every member of the household who gives his time to work on a farm business, will get an amount of money which is called income. Pig farming is one of the livestock sector businesses that are run in rural areas in Minahasa Regency ${ }^{[1-2]}$. Some people in the Tenga District, South Minahasa Regency, also raise pigs. Information from the published results obtained ${ }^{[3]}$, TengaDistrict has a large population of pigs (third place) in South Minahasa Regency, was 2,992 heads. Based on observations, it is known that pig farming in Tenga District, South Minahasa Regency is cultivated semiintensively, that is, pigs are kept in pens, either far away from or close to residential areas. Pig pen that is far from residential areas was usually a farm owned by farmers. There are also farmers who rent land to build a pig pen, on the grounds that the location is close to other pig pens.

Labor plays an important role as a factor of production, especially in carrying out the management of a business. Human resources are very important and influence the achievement of business goals. There are two functions carried out by the workforce in achieving business goals [4] such as managerial functions and operational functions. In addition, the amount of labor used in a business is closely related to labor absorption. Especially in rural areas, agricultural business is an effort that is able to absorb labor, so that it can reduce unemployment ${ }^{[5]}$. The pig farming 
business uses family labor such as the farmer and his wife, where the farmers mostly work on pig farming. This is in accordance with the research ${ }^{[6]}$, that the farmer as the head of the household is responsible for the survival and welfare of his family. Working time on a pig farm will generate some income. A person as a provider of labor, gives his time to work in a business, is influenced by the wages of the business. A person will allocate his time in the labor market for wages and satisfaction. The time allocation model is a combination of choices between income and leisure time that provides the same satisfaction ${ }^{[7]}$.

The problem is, farmers generally work on pig farms and also work on farms and non-farms, so farmers have to make decisions about working hours in some of the businesses they are engaged in. Based on observations, farmers work longer on farming than pig farming, so farmers tend to decide to work first on farming (coconut, maize and rice) then on pig farming. However, wages are the main consideration for farmers in deciding the amount of time to be allocated to a business. Farmers work for wages and tend to work in businesses that pay higher wages. If the wages from farming are high enough, the farmers tend to work more on farming and work less on pig farming. The observations show that the wages of pig farming vary due to the input and output prices. If the wages received are high enough, the farmers tend to work in pig farming. Working time on a pig farm has variations for each farmer, according to the number of livestock being raised. Pig farmers in Tenga District, South Minahasa Regency, have 1-6 sows with a working time of about 2-5 hours/day. Based on the research results ${ }^{[1]}$, working time on a pig farm with thirty pigs can be done by one worker.

Research on the factors that affect the allocation of working time in pig farming is important, so that it can solve the problems experienced by farmers. Research on the allocation of working time and the factors that influence it has been conducted by several researchers [8-12]. This study is different from previous studies, especially in the use of variables that affect the allocation of working time in pig farming, such as the wage variable for working in pig farming and the variable working time allocation on the farm. This research is important to do to obtain information related to problem solving.

\section{MATERIAL AND METHODS Sampling methods and data collection}

This research was conducted in Tenga District, South Minahasa Regency for 2 months, from December 2020 to January 2021. This study used primary and secondary data. Primary data were obtained from farmers through in-depth interviews using questionnaires to farmers in Tenga District, such as age, education level, number of pigs, farming experience, number of household members, labor, wages and working time. Secondary data were obtained from the publication of the Central Bureau of Statistics and the Agricultural Extension Center. The location is determined by the purposive sampling method [13], which is deliberately based on the consideration that the area has a large population of pigs. The selected villages were Tenga Village, Pakuweru Village and Pakuure Village. The sample of pig farmers was determined using the total quota sampling method ${ }^{[13]}$, namely all pig farmers in the three sample villages with a total of 37 farmers.

\section{Data analysis}

Research on the allocation of labor time for pig farming in Tenga District, South Minahasa Regency uses the following multiple regression analysis model.

$Y=a_{0}+a_{1} \ln X_{1}+a_{2} \ln X_{2}+a_{3} \ln X_{3}+a_{4} \ln X_{4}+e$

Where $\mathrm{Y}$ is the allocation of labor time in pig farming (working people's day/year), $X_{1}$ is the allocation of labor time in farming (working people's day/year), $\mathrm{X}_{2}$ is the wage for working in pig farming (IDR/working people's day), $\mathrm{X}_{3}$ is the 
number of pigs (head/year), and $\mathrm{X}_{4}$ is the number of household members (people).

\section{RESULT AND DISCUSSION \\ Characteristics of Pig Farming}

The age of pig farmers varies between 20-73 years. The results showed that the age of the farmers was between 2064 years, so that they were included in the productive age category in accordance with Law Number 13 of 2003. Farmers with productive age have labor that can work optimally ${ }^{[1]}$.The education level of pig farmers varies at graduates from junior high school, high school and university graduates. Farmers in general graduated from high school by $67.57 \%$. With this level of education, farmers have skills in raising pigs, and are able to raise pigs so that they can benefit. Formal educational background is one of the supporting factors for understanding the development and management patterns of pig farming [14].

The farming experience varies between 1-28 years, of which $72.91 \%$ have farming experience, namely 1-14 years. This situation is in accordance with the results of the study that $92 \%$ of respondents have experience in farming pigs for more than 5 years [14]. Labor is defined as the allocation of labor for household members to pig farming. Based on the results of research [1] that the workforce in the household consists of farmers, farmer's wives and children. This result is different from the current research, in which pig farms are raised by farmers or farmers' wives. The farmer's wife works only for a short period of time to replace the farmer who is temporarily working on other farms. This is in accordance with research [16] which shows that farmers have more working time than other household members. This is because the wife is more busy taking care of the household, while the children are in school [17]. Likewise with research [14] related to the management of pig farming, respondents rely more on men as their main workers and wives just to help. Farmers allocate work time ranging from 3 hours which is done every day such as mixing feed, feeding and drinking livestock, cleaning stables, and washing livestock which is done by domestic workers. The number of working hours in pig farming by raising an average of 26 pigs is done by 1 person or the farmer himself. The results showed that raising pigs routinely every day was done by the breeders themselves, this is in line with the research [15] [1].

The allocation of labor time is the number of hours of work that the worker spends on a combination model of pig breeding and fattening, in farming such as coconut, maize and rice, and non-farming. The average allocation of working time in the business is described in Table 1 .

Table 1: Average Allocated Working Time in the Business

\begin{tabular}{|c|c|c|}
\hline Type of business & $\begin{array}{c}\text { Number of Hours Worked } \\
\text { (Working person's day/year) }\end{array}$ & Percentage \\
\hline Pig farming & 106,57 & 32 \\
\hline On Farming & 143,64 & 42 \\
\hline Non Farming & 89,78 & 26 \\
\hline
\end{tabular}

Based on Table 1, it is known that the workforce prioritizes working time in farming, which is $42 \%$ and in pig farming, it is only $32 \%$, also in non-farming, only $26 \%$. The amount of working time on pig farming is described in Table 2 below.

\begin{tabular}{|} 
Table 2: The Amount Of Working Time On Pig Farming \\
\begin{tabular}{|c|c|}
\hline $\begin{array}{c}\text { Number of Hours Worked } \\
\text { (working person's day/year) }\end{array}$ & Percentage \\
\hline $75-110$ & 32.43 \\
\hline $112-125$ & 40.54 \\
\hline $126-150$ & 27.03 \\
\hline
\end{tabular}
\end{tabular}

Based on Table 2, it is known that there are $40.54 \%$ of farmers who allocate 112-125 working person's day/year of working time. The number of working hours in pig farming can still be increased and pig farming is able to absorb labor in rural areas, especially pig farming.

\section{Factors Affecting the Allocation of Labor Time in Pig Farming}

Testing of the factors that influence the allocation of labor time in pig farming is used multiple linear regression analysis, where the independent variable (independent) is the allocation of labor time in farming $\left(\mathrm{X}_{1}\right)$, labor wages in pig farming 
$\left(\mathrm{X}_{2}\right)$, the number of pigs. $\left(\mathrm{X}_{3}\right)$, and the number of household members $\left(\mathrm{X}_{4}\right)$ on the dependent variable (dependent) allocation of labor time in pig farming (Y), with the results of regression analysis described in Table 3 below.

Table 3: Results of Regression Analysis of Factors Affecting the Allocation of Labor Time in Pig Farming

\begin{tabular}{|l|c|}
\hline \multicolumn{1}{|c|}{ Variable } & Coefficient \\
\hline Constant & $-17,055^{* * *}$ \\
\hline Allocation of Working Time on Farming & $-0,210^{*}$ \\
\hline Wages for Pig Farming & $2,048^{* * *}$ \\
\hline Number of pigs & 0,048 \\
\hline Number of household members & 0,018 \\
\hline \multicolumn{2}{|c|}{$\begin{array}{c}\text { Information: ***) significant at } \boldsymbol{\alpha}=\mathbf{1 \%} \\
\text { significant at } \boldsymbol{\alpha}=\mathbf{1 0 \%}\end{array}$} \\
\hline
\end{tabular}

Based on the regression results in Table 3 , it is known that the equation model built includes a good model based on the R2 value of the regression results, namely 0.94 , which means variable variations, allocation of labor time in farming $\left(\mathrm{X}_{1}\right)$, wages for working in pig farming $\left(\mathrm{X}_{2}\right)$, number of livestock pigs $\left(\mathrm{X}_{3}\right)$, and the number of household members $\left(\mathrm{X}_{4}\right)$ can explain the variation in the allocation of labor time variables in pig farming (Y) by $94 \%$ and the remaining $6 \%$ is explained by variations in other variables outside the model or variables not examined by the researcher, namely variable age of farmers, level of education, farming experience. The results of the calculation of the F-count value, which is 107.38 , shows that the number is greater than the F-table value, which is 4.02 , which means that the variable of time allocation for labor in farming $\left(\mathrm{X}_{1}\right)$, wages for working in pig farming $\left(\mathrm{X}_{2}\right)$, the number of pigs $\left(\mathrm{X}_{3}\right)$, and the number of household members $\left(\mathrm{X}_{4}\right)$ together has a significant effect on the labor time allocation variable in pig farming $(\mathrm{Y})$.

\section{Allocation of Labor Time on Farming}

The variable of labor time allocation in farming has a significant effect on the allocation of labor time in pig farming ( $P$ $<0.1)$ with a regression coefficient of -0.22 . The regression coefficient of the labor time allocation variable in farming is negative and is in line with the expectation sign, meaning that every $1 \%$ increase in the allocation of labor time on farming will reduce the allocation of work time to pig farming by $0.22 \%$. Based on the research results, it is known that the more labor time allocation in farming, it will affect the labor time allocation in pig farming. The total allocation of labor time in farming is 143.64 working person's day/year and in pig farming 106.57 working person's day/year. Based on the research results, it is known that the allocation of labor time is more allocated to farming. The research of [16] where the allocation of family labor in farms other than livestock is greater than the allocation of family labor in livestock farming.

\section{Wages in Pig Farming}

The wage variable in pig farming has a significant effect on the allocation of labor time in pig farming $(\mathrm{P}<0.1)$ with a regression coefficient of 2.05. The regression coefficient is positive and is in accordance with the expectation sign, meaning that every $1 \%$ increase in wages for pig farming, the farmer will increase the working time allocation for pig farming by $2.05 \%$. Based on the research results, it is known that the more labor wages in pig farming, the more labor time allocation in pig farming. The results of this study are in accordance with research ${ }^{[18]}$ that there is a significant relationship between the level of wages and the allocation of working time, when wages increase, the work allocation will also increase.

\section{Number of pigs}

The variable number of pigs has no effect on the allocation of labor time in pig farming $(\mathrm{P}>0.1)$. This means that even if there is an increase in the number of pigs, it will not affect farmers in allocating working time to pig farming. The number of pig ownerships owned by pig breeders is currently 26 pigs/farmer. Based on the results of the research, the number of pig ownership in Tenga Village, Pakuure Village, and Pakuweru Village mostly raised 64 pigs and was only done by 1 person or the farmer himself. As research ${ }^{[1]}$ 
found that the amount of time working in a pig farming business with a total of 30 pigs ownership can be done by 1 worker.

\section{Number of household members}

The variable number of household members has no effect on the allocation of labor time in pig farming $(\mathrm{P}>0.1)$. This means that even though there is an increase in the number of household members, it will not affect farmers in allocating working time to pig farming. Based on the results of the research, the number of family members in Tenga Village, Pakuure Village, and Pakuweru Village is explained based on the average family dependency, namely 4 people/household and only 1 person who plays a role in managing the pig livestock business so it can be said that the number of family members has no influence. to the allocation of working time in the pig farming business. This study is in accordance with the research of [19] that family dependents have no significant effect on household work time allocation.

\section{CONCLUSION}

The factors of allocation of labor time in farming, wages of work in pig farming, the number of livestock ownership, and the number of family members all influence the allocation of labor time in pig farming. The factors that greatly influence the allocation of labor time in pig farming are the allocation of labor time in farming and the wages of pig farming.

\section{Acknowledgement: None}

\section{Conflict of Interest: None}

\section{Source of Funding: None}

\section{REFERENCES}

1. Sarajar MJ, Elly F H, Wantasen Eand Umboh S J K 2019Analisis Usaha Ternak Babi di Kecamatan Sonder Kabupaten Minahasa (Zootec)vol39 (Fakultas Peternakan Universitas Sam Ratulangi) $\mathrm{p}$ 276-283.

2. Santa N M andWantasen E 2018Profit Analysis Of Pig Farming In Rural
Comunities In Minahasa Regency Of North Sulawesi (JITAA) vol 43 (Fakultas Peternakan Universitas Diponegoro) p 289295

3. Anon 2019 BPS Kabupaten Minahasa Selatan 2019 Kabupaten Minahasa Selatan Dalam Angka

4. Abdullah, H2017Peranan Manajemen Sumberdaya Manusia dalam Organisasi (Waria)edisi 51

5. MarwantiSD and Barokah U 2011Dinamika Peranan Sektor Pertanian dalam Penyerapan Tenaga Kerja dan Strategi Peningkatan Produktivitas Tenaga Kerja Sektor Pertanian di Kawasan Subosuka Wonosraten (Journal Of Rural and Development)vol II.

6. Hutabarat SJ, Sajow A A, Lombogia S O B, Warouw Z M 2021Pengaruh Penyuluhan Terhadap Pendapatan Peternak Babi di Desa Kiawa Dua Timur Kecamatan Kawangkoan Utara (Zootec)vol41(Fakultas Peternakan Universitas Sam Ratulangi) p 205-213

7. Becker G S 1965 A theory of the allocation of time (The Economic Journal) vol $75 \mathrm{p}$ 493-517

8. Wahyuni N 2014Alokasi Waktu Kerja Dan Pendapatan Peternak Sapi Potong di Kecamatan Megang Sakti Kabupaten Musi Rawas (Societa)vol 3 p 58-63.

9. Kasmiyati A P and Priyanti2014Peranan dan Alokasi Waktu Tenaga Kerja Perempuan dalam Usaha Ternak Sapi Potong di Jawa Timur. Prosiding Seminar Internasinal Teknologi Peternakan dan veteriner $\mathrm{p}$ 278-288.

10. RosmawatiH 2014 Analisis Curahan Waktu Tenaga Kerja Wanita pada Usaha Ternak Sapi Potong di Desa Mendayun Kecamatan Madang Suku IKabupaten OKU Timur (AgrIBA) No 2 p 17-26.

11. Alam, A2013Curahan Waktu Kerja Keluarga Pada Usaha Peternakan Kambing di Kecamatan Leihitu Kabupaten Maluku Tengah (Agrinimal)vol 3 p 47-83

12. IsyantoAY 2015 Faktor-Faktor Yang Berpengaruh Terhadap Curahan Waktu Kerja Pada Usaha Penggemukan Sapi Potong di Kabupaten Ciamis (Mimbar Agribisnis) vol 1.

13. Sugiyono2018 Metode Penelitian Kuantitatif, Kualitatif, dan R\&D (Bandung: Alfabeta)

14. SuranjayaIG, Dewantari M, Parimartha I K W and Sukanata I W 2017Profile Usaha Peternakan Babi Skala Kecil di Desa Puhu 
Kecamatan Payangan Kabupaten Gianyar (Majalah Ilmiah Peternakan)vol 20 p79-83.

15. Mengu YS, Lole V R and Niron S S 2017 Kinerja Produksi dan Ekonomi Usaha Penggemukkan Ternak Babi Program Pengembangan Usaha Agribisnis Pedesaan (Puap) di Kecamatan Adonara Timur (Jurnal Nukleus Peternakan)vol 4 p 71-82.

16. Tendean M, Umboh S J K, Wantasen E and Elly F H 2019Alokasi Tenaga Kerja Rumahtangga Tani Penerima Bantuan Modal Ternak Sapi di Kecamatan Kawangkoan Barat (Zootec) vol 39 p 203212.

17. Tatipikalawan and Jomina 2012 Analisis Produktiitas Tenaga Kerja Keluarga Pada Usaha Peternakan Kerbau di Pulau Moa Kabupaten Maluku Barat Daya (Skripsi Jurusan Peternakan Fakultas Pertanian Universitas Pattimura. Ambon)
18. WulandariRD2016Alokasi Waktu Kerja Rumah Tangga Buruh Tani Perkebunan Tebu dan Variabel Sosial Ekonomi yang Mempengaruhi Studi pada Desa Sukosari Kecamatan Gondanglegi Kabupaten Malang (Jurnal Ilmiah).

19. SirappaP, Sunarso and Sumekar W 2017Faktor-Faktor yang Mempengaruhi Curahan Tenaga Kerja Keluarga dalam Pengembangan Ekonomi Usaha Sapi Perah di Kecamatan Ungaran Barat, Kabupaten Semarang (Jurnal Agrisocionomics) vol 1 p72-84.

How to cite this article: Nansi Margret Santa, Merry Adelien Veibe Manese, Poulla Oliva Viviaan Waleleng Waleleng. Allocation of labor time on pig farming in Tenga District South Minahasa Regency. International Journal of Research and Review. 2022; 9(1): 446-451. DOI: https://doi.org/10.52403/ijrr.20220150 